NISTIR 8169

\title{
NIST/NIH Vitamin D Metabolites Quality Assurance Program Report of Participant Results: Summer 2016 Comparability Study (Exercise 12)
}

\author{
Mary Bedner \\ Carolyn Q. Burdette
}

This publication is available free of charge from:

https://doi.org/10.6028/NIST.IR.8169

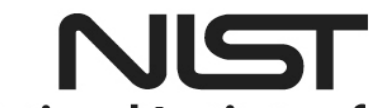

National Institute of Standards and Technology U.S. Department of Commerce 
NISTIR 8169

\title{
NIST/NIH Vitamin D Metabolites Quality Assurance Program Report of Participant Results: Summer 2016 Comparability Study (Exercise 12)
}

\author{
Mary Bedner \\ Carolyn Q. Burdette \\ Chemical Sciences Division \\ Material Measurement Laboratory
}

This publication is available free of charge from:

https://doi.org/10.6028/NIST.IR.8169

July 2017

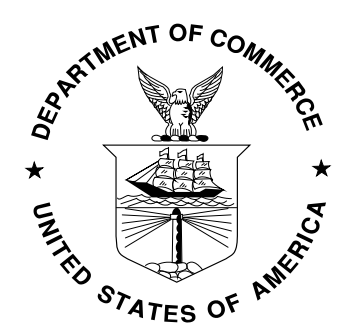

U.S. Department of Commerce Wilbur L. Ross, Jr., Secretary

National Institute of Standards and Technology Kent Rochford, Acting NIST Director and Under Secretary of Commerce for Standards and Technology 


\begin{abstract}
The National Institute of Standards and Technology (NIST) established the Vitamin D Metabolites Quality Assurance Program (VitDQAP) in collaboration with the National Institutes of Health (NIH) Office of Dietary Supplements in 2009. Participants in the twelfth and final exercise of this program, the Summer 2016 Comparability Study, were asked to use the methodology of their choice to measure concentrations of 25-hydroxyvitamin D in pooled human serum control and study materials distributed by NIST. The study materials consisted of candidate SRM 968f Fat-Soluble Vitamins in Human Serum, Level 1 (SRM 968f L1), and Level 2 (SRM 968f L2). Standard Reference Material (SRM) 968d Fat-Soluble Vitamins, Carotenoids, and Cholesterol in Human Serum Level 1 was provided as a control material. Participants provided their data to NIST, where it was compiled and evaluated for trueness relative to the NIST value and concordance within the participant community. A report of results was provided to all participants of the study, and laboratories were identified by code numbers known only to them. The results from this twelfth study are reported along with a summary of the analytical methods used.
\end{abstract}




\section{NIST/NIH VITAMIN D METABOLITES QUALITY ASSURANCE PROGRAM \\ REPORT OF PARTICIPANT RESULTS SUMMER 2016 COMPARABILITY STUDY: EXERCISE 12}

\section{OVERVIEW OF THE SUMMER 2016 STUDY}

For the Summer 2016 comparability study of the collaborative National Institute of Standards and Technology and National Institutes of Health (NIST/NIH) Vitamin D Metabolites Quality Assurance Program (VitDQAP), human serum control and study materials were distributed to participants for evaluation. Standard Reference Material (SRM) 968d Fat-Soluble Vitamins, Carotenoids, and Cholesterol in Human Serum Level 1 (SRM 968d L1) was provided as a control material for assay validation. For SRM 968d L1 (Control), the participants were provided the NIST target values within the data reporting sheet so that they could qualify their methods prior to analyzing the study samples. The study materials consisted of two vials, each containing a sample of pooled human serum. In this study, Vial A and Vial B were candidate SRM 968f Fat-Soluble Vitamins in Human Serum, Level 1 (SRM 968f L1), and Level 2 (SRM 968f L2), respectively, both of which contain endogenous levels of the vitamin D metabolites. Participants were asked to determine 25-hydroxyvitamin D in each of the human serum control and study samples. Individual concentration values for 25-hydroxyvitamin $\mathrm{D}_{3}$ (25( $\left.\mathrm{OH}) \mathrm{D}_{3}\right)$, 25-hydroxyvitamin $\mathrm{D}_{2}\left(25(\mathrm{OH}) \mathrm{D}_{2}\right)$, and 3-epi-25-hydroxyvitamin $\mathrm{D}_{3}$ (3epi-25( $(\mathrm{OH}) \mathrm{D}_{3}$ ) were requested along with a total concentration of 25-hydroxyvitamin $\mathrm{D}$ : $25(\mathrm{OH}) \mathrm{D}_{\text {Total }}=25(\mathrm{OH}) \mathrm{D}_{2}+25(\mathrm{OH}) \mathrm{D}_{3}$.

There were 36 participants and 38 datasets (2 participants, Labs 056 and 214, provided data from two methods) in the Summer 2016 comparability study. Eight (8) of the datasets originated from immunoassay (IA) techniques, including six (6) from chemiluminescence immunoassay (CLIA), and two from enzyme immunoassay (EIA). Appendix A-1 summarizes the IA methods used by the participants. Thirty (30) of the datasets originated from liquid chromatographic (LC) methods; of those, 28 were from LC with tandem mass spectrometric detection (LC-MS/MS), and two (2) were from LC with ultraviolet absorbance detection (LC-UV). The LC-MS/MS methods are referred to as LC-MS ${ }^{\mathrm{n}}$. A summary of the LC MS ${ }^{\mathrm{n}}$ and LC-UV methods used by the participants may be found in Appendices A-2 and A-3, respectively. Note: The methodological information provided on the data reporting sheet was used to update the list from previous comparability studies. For participants that did not provide method details for the Summer 2016 study, the information in the appendices were not edited and may not be current.

The raw data received from all participants for the control and study materials are summarized in Appendix B. IA methods do not distinguish between $25(\mathrm{OH}) \mathrm{D}_{3}$ and $25(\mathrm{OH})_{2}$ and are purported not to detect endogenous 3-epi-25( $\left.\mathrm{OH}\right) \mathrm{D}_{3}$. Therefore, IA participants reported single values for $25(\mathrm{OH}) \mathrm{D}_{\text {Total }}$. In contrast, the LC methods can separate the vitamin D metabolites. All LC participants reported values for $25(\mathrm{OH}) \mathrm{D}_{\text {Total, }}$, 29 participants reported values for $25(\mathrm{OH}) \mathrm{D}_{3}$, nine (9) LC participants reported results 
for $25(\mathrm{OH}) \mathrm{D}_{2}$, and six (6) participants reported results for 3-epi-25(OH) $\mathrm{D}_{3}$ in at least one of the control and study materials. One (1) participant also reported values for 24(R), 25dihydroxyvitamin $\mathrm{D}_{3}\left(24(\mathrm{R}), 25(\mathrm{OH})_{2} \mathrm{D}_{3}\right)$ and vitamin $\mathrm{D}_{3}$, which are not represented in Appendix B.

Appendix B also provides the summarized NIST results for each of the serum materials. A detailed description of the NIST methods is provided in the next section of this report.

\section{SUMMARY OF NIST METHOD USED TO EVALUATE THE CONTROL AND STUDY MATERIALS}

NIST used isotope dilution LC-MS/MS (ID-LC-MS/MS) [1] to determine the vitamin D metabolites $\left(25(\mathrm{OH}) \mathrm{D}_{3}, 25(\mathrm{OH}) \mathrm{D}_{2}\right.$, and 3-epi-25(OH) $\left.\mathrm{D}_{3}\right)$ in the control and study materials evaluated in this comparability study. The ID-LC-MS/MS approach is a reference measurement procedure (RMP) for $25(\mathrm{OH}) \mathrm{D}_{3}$ and $25(\mathrm{OH}) \mathrm{D}_{2}$ that is recognized by the Joint Committee for Traceability in Laboratory Medicine (JCTLM).

The NIST values for 25(OH) $\mathrm{D}_{3}, 25(\mathrm{OH}) \mathrm{D}_{2}$, and 3-epi-25(OH) $\mathrm{D}_{3}$ in SRM $968 \mathrm{f} \mathrm{L} 1$ (Vial A) and SRM 968f L2 (Vial B) are reported with approximate $95 \%$ expanded uncertainties $(U)$ that incorporate components for measurement variability and measurement uncertainty associated with the density of the materials and the purity of the reference standards. In addition, the measurements include a $1 \%$ type B uncertainty for unknown systematic errors, which is consistent with the practice used at NIST for clinical measurements [1]. For SRM 968d L1 (Control), the NIST values for 25(OH)D $\mathrm{D}_{3}$ and 3epi-25(OH)D $\mathrm{D}_{3}$ are reported as described for SRM 968f L1 (Vial A) and SRM 968f L2 (Vial B), but the value for $25(\mathrm{OH}) \mathrm{D}_{2}$ was estimated to be $0.1 \mathrm{ng} / \mathrm{mL}$.

The values for 25(OH)D $\mathrm{D}_{\text {Total }}$ in SRM $968 \mathrm{f}$ L1 (Vial A), SRM 968f L2 (Vial B) and SRM 968d L1 (Control) are the sum of the individual values for 25(OH) $\mathrm{D}_{3}$ and $25(\mathrm{OH}) \mathrm{D}_{2}$, and the expanded uncertainty incorporates measurement uncertainties for the two analytes.

\footnotetext{
${ }^{1}$ Tai, S. S.-C.; Bedner, M.; Phinney, K.W.; Anal. Chem. 2010 82, 1942-1948.
} 


\section{SUMMER 2016 COMPARABILITY STUDY RESULTS AND DISCUSSION}

\section{Results for 25(OH)DTotal}

A summary of the individual participant data for total 25-hydroxyvitamin D (25(OH)D Total) in SRM 968f L1 (Vial A), SRM 968f L2 (Vial B), and SRM 968d L1 (Control) is provided in Table 1.

The community results are summarized at the bottom of Table $\mathbf{1}$ for all reported methods, the IA methods only, the LC methods only, and the LC-MS ${ }^{\mathrm{n}}$ methods only. The community results include the total number of quantitative values reported $(N)$; the median value; the median absolute deviation from the median (MADe), a robust estimate of the standard deviation; and the percent coefficient of variation (CV\%).

Table 1 also presents the NIST results for $25(\mathrm{OH}) \mathrm{D}_{\text {Total }}$ in the control and the two study materials. 
Table 1. Summary of participant data for $25(\mathrm{OH}) \mathrm{D}_{\text {Total }}(\mathrm{ng} / \mathrm{mL})$ in SRM 968f L1 (Vial A), SRM 968f L2 (Vial B), and SRM 968d L1 (Control).

\begin{tabular}{|c|c|c|c|c|}
\hline & & SRM 968f L1 & SRM 968f L2 & SRM 968d L1 \\
\hline $\mathrm{Lab}$ & Method & Vial A & Vial B & Control \\
\hline 026 & LC-MS/MS & 14.5 & 15.9 & 12.8 \\
\hline 030b & LC-MS/MS & 21.0 & 21.8 & 12.5 \\
\hline $056 a$ & LC-MS/MS & 13.1 & 17.2 & 12.0 \\
\hline 056b & LC-MS/MS & 13.9 & 16.8 & 12.9 \\
\hline 060 & LC-MS/MS & 13.9 & 18.6 & 12.7 \\
\hline 110 & LC-UV & 13.0 & 18.4 & 12.5 \\
\hline 116 & LC-MS/MS & 14.8 & 17.6 & 13.9 \\
\hline 127 & EIA & 21.8 & 21.0 & 18.6 \\
\hline 150 & LC-MS/MS & 13.0 & 17.0 & 13.0 \\
\hline $161 b$ & LC-MS/MS & 10.8 & 16.6 & 13.5 \\
\hline 188 & CLIA & 17.5 & 14.5 & 12.5 \\
\hline 194 & LC-MS/MS & 14.6 & 16.4 & 14.1 \\
\hline 196 & CLIA & 18.8 & 16.9 & 14.6 \\
\hline 197 & LC-MS/MS & 12.7 & 17.7 & 12.3 \\
\hline 199 & LC-MS/MS & 13.4 & 16.7 & 13.1 \\
\hline $204 b$ & LC-MS/MS & 12.6 & 16.2 & 12.4 \\
\hline 209 & LC-MS/MS & 14.6 & 20.1 & 11.8 \\
\hline 211 & LC-MS/MS & 13.0 & 19.0 & 13.1 \\
\hline $214 b$ & CLIA & 18.5 & 15.0 & 17.2 \\
\hline $214 c$ & LC-MS/MS & 13.3 & 16.4 & 12.7 \\
\hline 215 & LC-MS/MS & 12.8 & 17.2 & 12.8 \\
\hline 216 & LC-MS/MS & 13.7 & 16.8 & 12.7 \\
\hline 217 & LC-MS/MS & 16.0 & 20.8 & 18.4 \\
\hline $218 a$ & CLIA & 12.4 & 14.2 & 16.5 \\
\hline $221 b$ & LC-UV & 14.0 & 18.0 & 19.0 \\
\hline 225 & LC-MS/MS & 13.7 & 16.6 & 12.7 \\
\hline $228 a$ & LC-MS/MS & 13.2 & 15.8 & 12.4 \\
\hline 241 & LC-MS/MS & 14.0 & 17.4 & 13.0 \\
\hline 244 & LC-MS/MS & 12.3 & 15.6 & 12.7 \\
\hline 249 & LC-MS/MS & 12.7 & 18.0 & 13.3 \\
\hline 251 & LC-MS/MS & 16.0 & 20.0 & $\mathrm{n} / \mathrm{r}$ \\
\hline 255 & LC-MS/MS & 15.3 & 17.4 & 13.6 \\
\hline 256 & CLIA & 19.3 & 15.2 & 12.4 \\
\hline 259 & LC-MS/MS & 11.4 & 13.5 & 13.2 \\
\hline 261 & CLIA & 19.2 & 35.9 & 13.5 \\
\hline 271 & LC-MS/MS & 16.7 & 22.1 & 15.2 \\
\hline 272 & LC-MS/MS & 13.6 & 16.8 & 12.6 \\
\hline 273 & EIA & 18.6 & 18.1 & 15.1 \\
\hline & $N$ & 38 & 38 & 37 \\
\hline$=8$ & Median & 13.9 & 17.1 & 13.0 \\
\hline$\varangle \frac{5}{0}$ & MADe & 1.7 & 1.4 & 0.8 \\
\hline & $\mathrm{CV} \%$ & 12 & 8.3 & 6.1 \\
\hline & $N$ & 8 & 8 & 8 \\
\hline$\varangle \stackrel{0}{c}$ & Median & 18.7 & 16.1 & 14.9 \\
\hline$-\bar{\Xi}$ & MADe & 0.8 & 2.5 & 3.0 \\
\hline & CV\% & 4.4 & 16 & 20 \\
\hline & $N$ & 30 & 30 & 29 \\
\hline $0 \stackrel{0}{0}$ & Median & 13.6 & 17.2 & 12.8 \\
\hline$\sqsupset \bar{\Xi}$ & MADe & 1.3 & 1.2 & 0.4 \\
\hline & CV\% & 9.2 & 6.9 & 3.5 \\
\hline & $N$ & 28 & 28 & 27 \\
\hline$\sum^{0}$ & Median & 13.6 & 17.1 & 12.8 \\
\hline نं & MADe & 1.3 & 1.0 & 0.4 \\
\hline ـ & CV\% & 9.8 & 6.0 & 3.5 \\
\hline & NIST Value & 13.2 & 15.8 & 12.5 \\
\hline & $U$ & 0.5 & 0.5 & 0.4 \\
\hline
\end{tabular}


For all participant datasets, the single reported values for $25(\mathrm{OH}) \mathrm{D}_{\text {Total }}$ in SRM $968 \mathrm{~L}$ 1 (Vial A), SRM 968f L2 (Vial B), and SRM 968d L1 (Control) are plotted in Figure 1, Figure 2, and Figure 3, respectively. The results from immunoassay methods are displayed with open dark blue circles $(\circ)$, and the results from the LC-based methods are displayed with open light blue circles $(\circ)$. The results from the individual methods (CLIA, EIA, LC-MS ${ }^{\mathrm{n}}$, and LC-UV) were sorted from the lowest to the highest value and are plotted separately, as roughly indicated by the x-axis labels. Table 1 should be crossreferenced to verify which methods correspond with which participant numbers.

From the single reported values for all datasets for a given technique (IA or LC), the consensus median and the consensus expanded uncertainty $(2 \times$ MADe $)$ were determined. For both of the major techniques (IA or LC) in each figure, the solid lines (- - and (- $\longrightarrow$ ) represent the consensus median, and the dashed lines (- - - -) and (- - - - ) represent the consensus expanded uncertainty interval (median $\pm 2 \times$ MADe). The laboratories with results that fall between the two dashed lines are within the consensus range for their technique (IA or LC).

The red lines (-) in each figure (Figures $1-3$ ) represent the NIST value and its associated uncertainty (i.e., value $\pm U$ ). NIST has confidence that the "true" value for each material lies within this interval. When these lines are not within the consensus ranges for each technique (IA or LC), then there may be method bias.

Specific results for each of the three study materials are summarized below. Note that the assessment is based on the actual reported values, not the lines and symbols, which have been enlarged to show detail and the laboratory number.

\section{SRM 968f L1 (Vial A): Figure 1}

- For the IA results, two reported values are outside of the consensus range (one CLIA, one EIA).

- For the LC results, three reported values are outside of the consensus range (all LC$\left.\mathrm{MS}^{\mathrm{n}}\right)$.

- The consensus median value and range for the IA results are significantly higher than both the NIST expanded uncertainty range (red lines) and the LC consensus range.

- The consensus median value for the LC results is comparable to the NIST expanded uncertainty range (red lines).

\section{SRM 968f L2 (Vial B): Figure 2}

- For the IA results, the data appear to be non-normally distributed, and the consensus variability is not well-described by the MADe estimation; however, one CLIA result is outside the consensus range.

- For the LC results, six LC-MS ${ }^{\mathrm{n}}$ values are outside the consensus range (all LC-MS ${ }^{\mathrm{n}}$ ). 
- The consensus median value for the IA results is comparable with the NIST expanded uncertainty range (red lines).

- The consensus median value for the LC results is higher than the NIST expanded uncertainty range (red lines).

- The NIST expanded uncertainty range (red lines) falls within the consensus range for both IA and LC.

\section{SRM 968d L1 (Control): Figure 3}

- The IA results appear to be non-normally distributed, and the consensus variability is not well-described by the MADe estimation but includes all of the IA data.

- For the LC results, six reported values are outside of the consensus range (five LC$\mathrm{MS}^{\mathrm{n}}$, one LC-UV).

- The consensus median value for the IA results is higher than the NIST expanded uncertainty range (red lines).

- The consensus median value for the LC results is comparable to the NIST expanded uncertainty range (red lines).

- The NIST expanded uncertainty range (red lines) falls within the consensus range for both IA and LC. 
Figure 1. Participant results for 25(OH)D Total in SRM 968f L1 (Vial A) as determined by immunoassay (CLIA and EIA) and LC (LC$\mathrm{MS}^{\mathrm{n}}$ and LC-UV) methods.

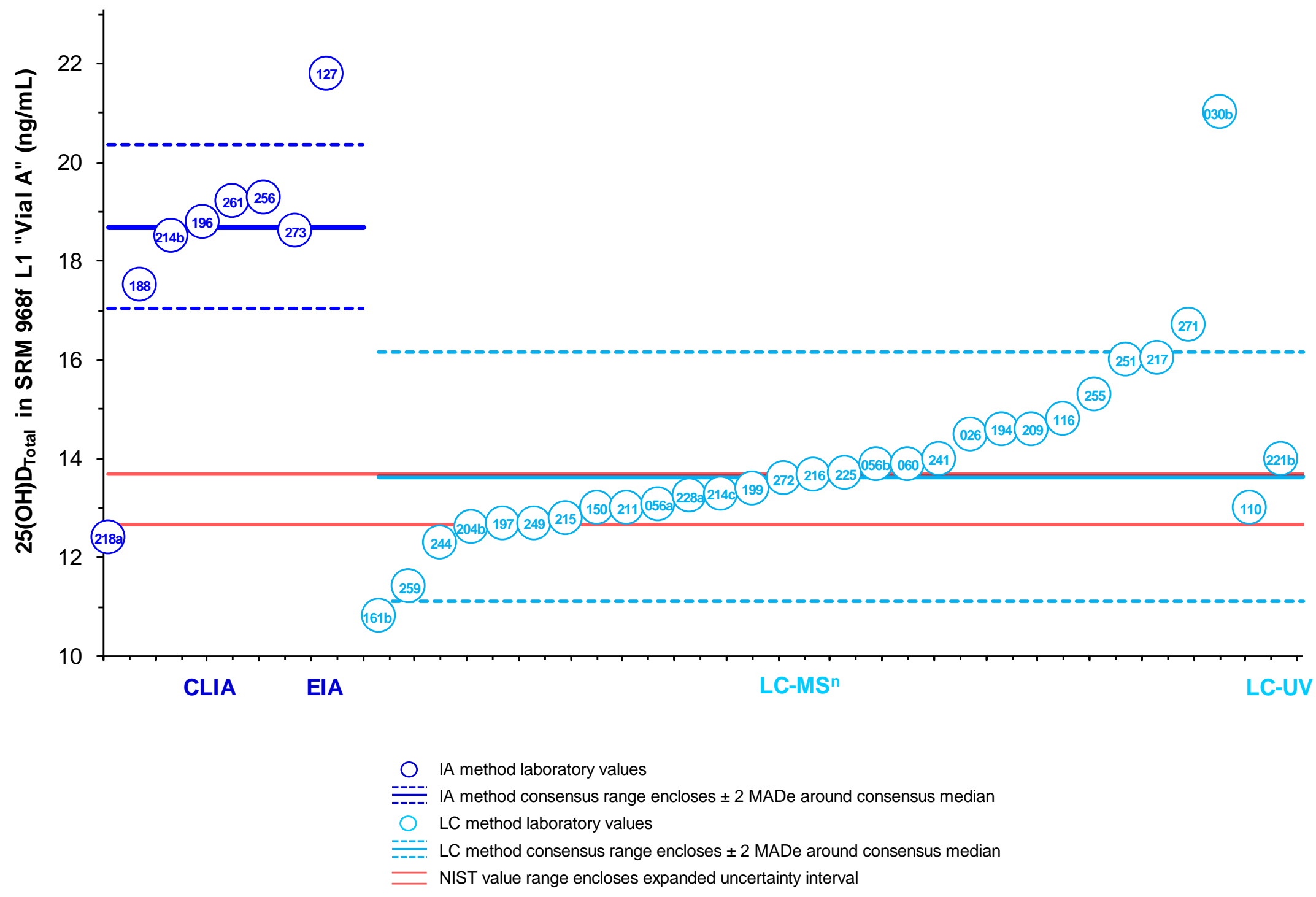


Figure 2. Participant results for 25(OH)D Total in SRM 968f L2 (Vial B) as determined by immunoassay (CLIA and EIA) and LC (LC$\mathrm{MS}^{\mathrm{n}}$ and LC-UV) methods.

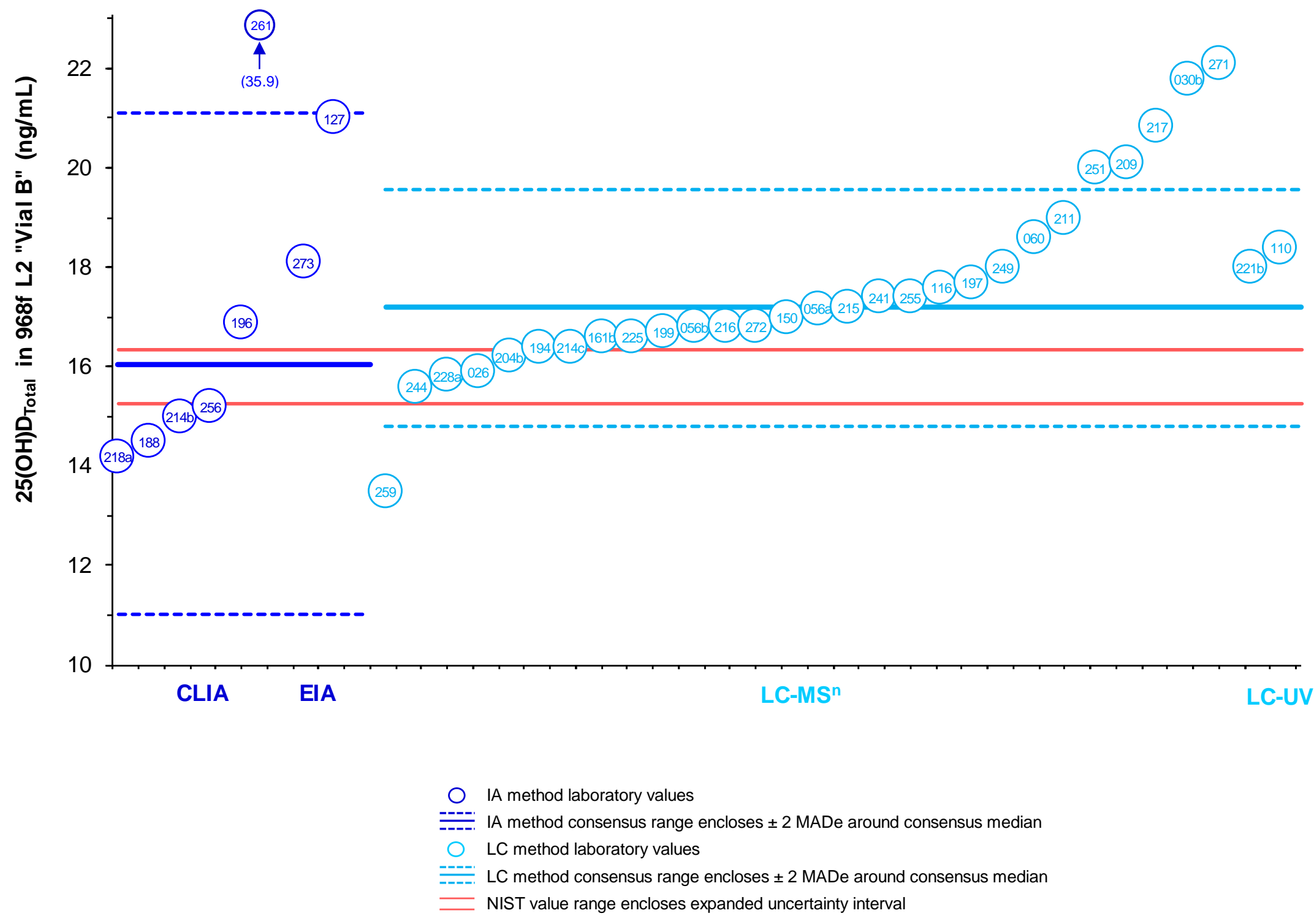


Figure 3. Participant results for 25(OH) $\mathrm{D}_{\text {Total }}$ in SRM 968d Level 1 (Control) as determined by immunoassay (CLIA and EIA) and LC (LC-MS ${ }^{\mathrm{n}}$ and LC-UV) methods.

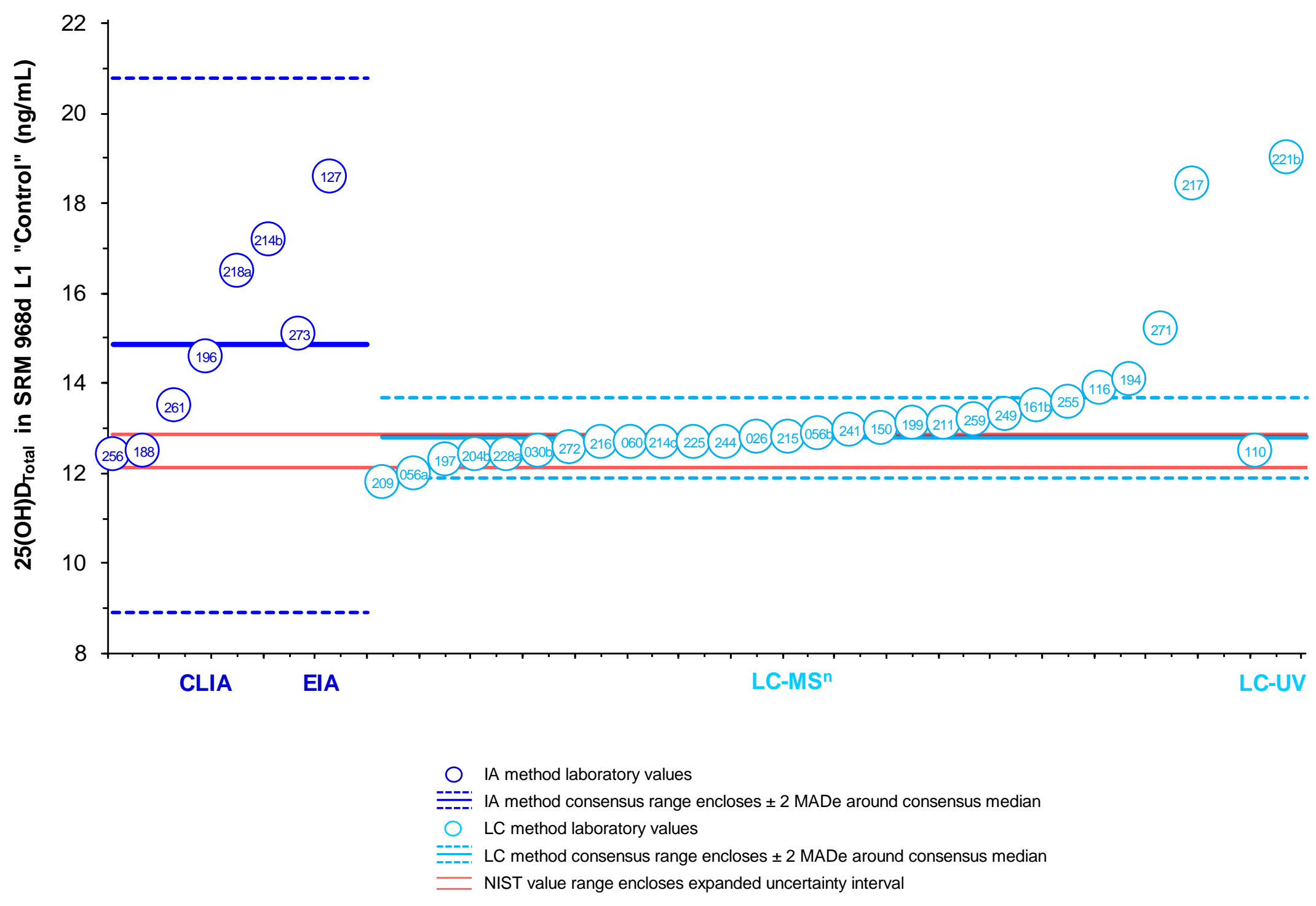


Figure 4 presents direct graphical comparisons of the 25(OH)D Total results for a) SRM 968f L1 (Vial A) and SRM 968f L2 (Vial B), and b) SRM 968f L2 (Vial B) and SRM 968d L1 (Control). In each plot, there are two blue consensus boxes, one for IA methods and one for LC methods (as indicated). Laboratory results that are within the consensus range for both study materials are within the blue consensus boxes. Conversely, laboratory results that fall outside of (or on the edge of) either of the consensus boxes are not included in the consensus ranges for their technique and are highlighted with their laboratory code numbers. In each plot, the NIST values for the materials are denoted with a red diamond symbol $(\diamond)$, and the Youden line $(y=x)$ centered on the NIST value is illustrated by a red line (-) across the magnitude of the $y$-axis and $x$-axis, respectively.

Specific results as assessed from the Youden comparison plots are summarized below.

\section{SRM 968f L1 (Vial A) and SRM 968f L2 (Vial B): Figure 4 a}

- IA results that are not included in the consensus ranges include: 127, 218a, and 261.

- LC results that are not included in the consensus ranges include: 030b, 161b, 209, 217, 251, 259, and 271.

- The Youden line runs through the center of the LC consensus box, illustrating that the LC results are in agreement generally with each other and with the NIST results for these materials.

- The linear trend of the LC data (results closely aligned with the Youden line) indicates participant-specific analytical bias.

- The Youden line barely intercepts the upper left-hand corner of the IA consensus box, illustrating the bias of the IA results for SRM 968f L1 (Vial A).

\section{SRM 968f L2 (Vial B) and SRM 968d L1 (Control): Figure 4 b}

- The consensus box for the IA results is extremely large for these two materials, which hinders an assessment of the agreement with the Youden line or of the identification of outliers; however, the result for lab 261 is well outside of the consensus range.

- LC results that are not included in the consensus ranges include numbers 030b, 194, 209, 217, 221b, 259, and 271.

- The Youden line runs through the left side of the LC consensus box, illustrating the slight positive bias of the LC results for both of these materials.

- The lack of strong linear trend (for the LC results) suggests either significant differences between SRM 968d L1 (Control) and SRM 968f L2 (Vial B) or the 'attractor' effect of participants knowing the correct value for the control. 
Figure 4. Youden comparison plot of the results for $25(\mathrm{OH}) \mathrm{D}_{\text {Total }}$ in a) SRM 968f L1 (Vial A) and SRM 968f L2 (Vial B) and b) SRM 968f L2 (Vial B) and SRM 968d L1 (Control) for all methods.
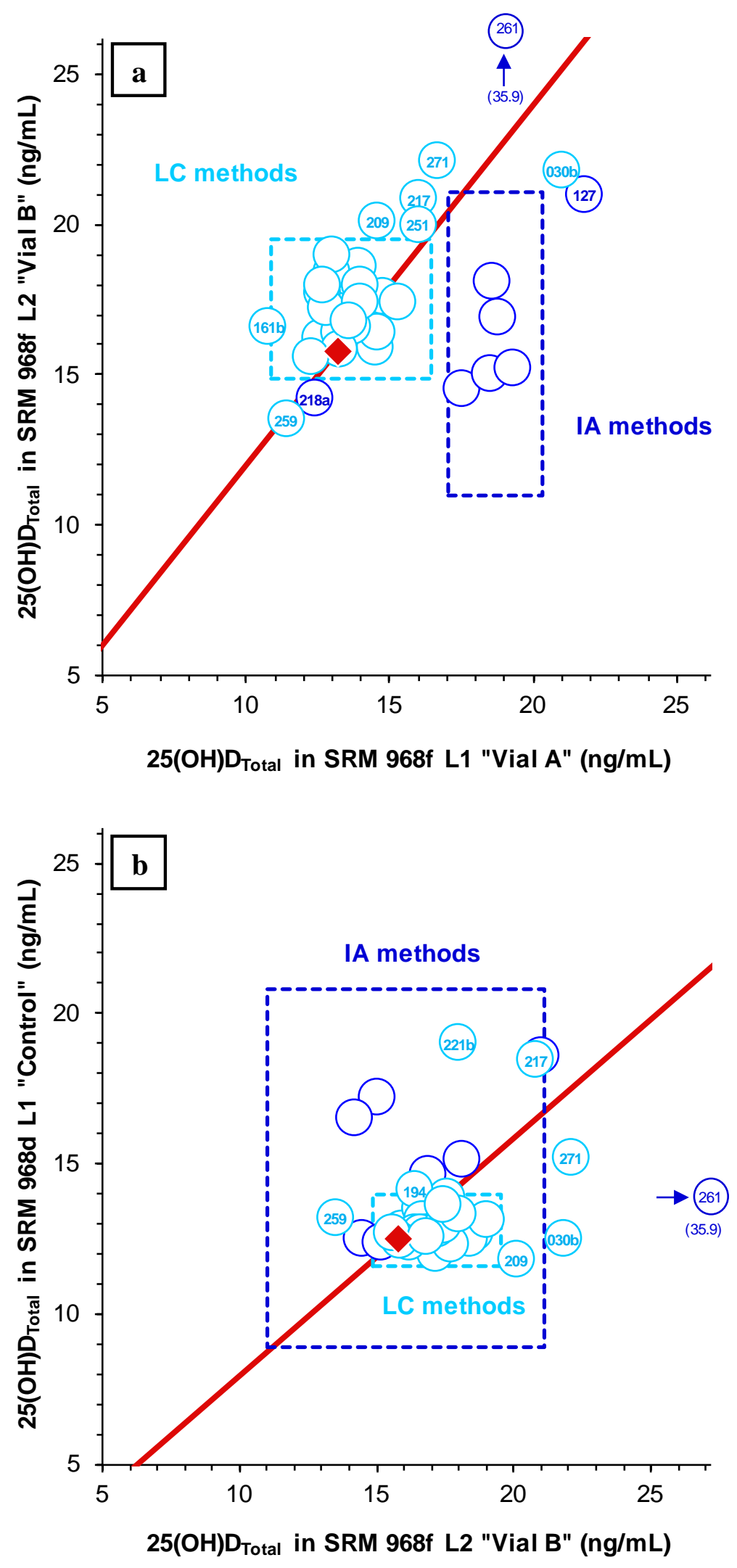


\section{Discussion of Results for 25(OH) $\mathbf{D}_{\text {Total }}$}

The Summer 2016 comparability study was the first to utilize the candidate SRM 968f study materials, both of which contain endogenous levels of the vitamin D metabolites. Furthermore, SRM 968f L1 (Vial A), SRM 968f L2 (Vial B) and SRM 968d L1 (Control) contain predominantly $25(\mathrm{OH}) \mathrm{D}_{3}$ as the metabolite contributing to $25(\mathrm{OH}) \mathrm{D}_{\text {Total }}$, and all three contain relatively comparable and low concentrations of $25(\mathrm{OH}) \mathrm{D}_{\text {Total }}$ based on the NIST values (value $\pm U$ ) of $13.2 \mathrm{ng} / \mathrm{mL} \pm 0.5 \mathrm{ng} / \mathrm{mL}, 15.8 \mathrm{ng} / \mathrm{mL} \pm 0.5 \mathrm{ng} / \mathrm{mL}$, and $12.5 \mathrm{ng} / \mathrm{mL} \pm 0.4 \mathrm{ng} / \mathrm{mL}$, respectively.

The all-method CV \%'s of $12 \%, 8.3 \%$, and $6.1 \%$ for SRM 968f L1 (Vial A), SRM $968 f$ L2 (Vial B), and (Control), respectively, are consistent with participant performance for other materials containing predominantly $25(\mathrm{OH}) \mathrm{D}_{3}$ that were evaluated in previous comparability studies of the VitDQAP. While the CV \% provides information about the comparability of the reported results to each other, it does not indicate the bias of the results relative to each of the two major techniques (IA or LC) or to the NIST values.

The IA median value for the SRM 968f L1 (Vial A) study material (with its expanded uncertainty $\pm 2 \times$ MADe) of $18.7 \mathrm{ng} / \mathrm{mL} \pm 1.6 \mathrm{ng} / \mathrm{mL}$ is biased high relative to both the expanded LC median value of $13.6 \mathrm{ng} / \mathrm{mL} \pm 2.6 \mathrm{ng} / \mathrm{mL}$ and the NIST value of $13.2 \mathrm{ng} / \mathrm{mL} \pm 0.5 \mathrm{ng} / \mathrm{mL}$; this represents a high bias of approximately $42 \%$ relative to the NIST value. Additionally, there is no overlap in the expanded uncertainty range for the reported IA methods and the LC and NIST results for this material, as evident in Figure 1 and Figure 4a. Interestingly, SRM 968d L1 (Control) contains very similar levels of 25(OH)D $\mathrm{D}_{\text {Total }}$ to SRM $968 \mathrm{f} \mathrm{L1}$ (Vial A), but the median IA result of $14.9 \mathrm{ng} / \mathrm{mL} \pm$ $6.0 \mathrm{ng} / \mathrm{mL}$ is biased less, or approximately $19 \%$ higher than the NIST value (Figure 3 ) of 12.5 $\mathrm{ng} / \mathrm{mL} \pm 0.4 \mathrm{ng} / \mathrm{mL}$ for this material. Lastly, the IA median result agrees generally with the NIST result for SRM 968f L2 (Vial B), as shown in Figure 2.

The LC median result of $17.2 \mathrm{ng} / \mathrm{mL} \pm 2.4 \mathrm{ng} / \mathrm{mL}$ for the SRM $968 \mathrm{f} \mathrm{L2} \mathrm{(Vial} \mathrm{B)} \mathrm{study} \mathrm{material} \mathrm{is}$ somewhat high relative to the NIST result of $15.8 \mathrm{ng} / \mathrm{mL} \pm 0.5 \mathrm{ng} / \mathrm{mL}$, representing a bias of approximately $9 \%$. Conversely, the LC median results agree with the NIST results for SRM $968 \mathrm{f}$ L1 (Vial A) and SRM 968d L1 (Control) (Figure 1 and Figure 3, respectively).

Given the similarity of the concentrations of $25(\mathrm{OH}) \mathrm{D}_{\text {Total }}$ in the three materials, it would be expected that the measurement trends would be the same for each technique if the same sample preparation, instrumental methods, and calibrants were used by each laboratory for all samples. The material-specific trends, which are particularly notable for the IA results, indicate that there are notable differences in the materials (i.e., matrix effects) influencing the results, or that measurements using these methods are not well-controlled at low $25(\mathrm{OH}) \mathrm{D}_{\text {Total }}$ levels due to factors such as differences in binding or non-linear behavior. The last factor that blurs an assessment of trends is that both LC and IA provided more accurate results for the control material than for the study samples, even though the levels are comparable in all three materials. We term this the 'attractor effect' of knowing the correct answer for SRM 968d L1 (Control). 


\section{LC Results for the Individual Metabolites}

Of the two major techniques IA and LC, only the LC methods can independently measure the individual metabolites $25(\mathrm{OH}) \mathrm{D}_{3}, 25(\mathrm{OH}) \mathrm{D}_{2}$, and 3-epi-25(OH) $\mathrm{D}_{3}$. In the Summer 2016 comparability study of the VitDQAP, the study materials and the control contained low albeit detectable amounts of the $25(\mathrm{OH}) \mathrm{D}_{2}$ and the 3-epi-25(OH) $\mathrm{D}_{3}$ metabolites. Of these two metabolites, only $25(\mathrm{OH}) \mathrm{D}_{2}$ is included as a component in the $25(\mathrm{OH}) \mathrm{D}_{\text {Total }}$ values.

The non-zero study results and the NIST values for $25(\mathrm{OH}) \mathrm{D}_{3}, 25(\mathrm{OH}) \mathrm{D}_{2}$, and 3-epi-25(OH) $\mathrm{D}_{3}$ for the study materials and the control are presented in Table 2, Table 3, and Table 4, respectively.

All the participating LC labs reported results for $25(\mathrm{OH}) \mathrm{D}_{3}$ (Table 2), the primary metabolite contributing to $25(\mathrm{OH}) \mathrm{D}_{\text {Total }}$. The community results for $25(\mathrm{OH}) \mathrm{D}_{3}$ displayed at the bottom of

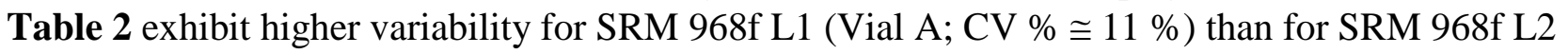
(Vial B) and SRM 968d L1 (Control), which both have a CV \% $\leq 7 \%$. The median values for 25(OH)D $D_{3}$ agree well with the NIST values for SRM 968f L1 (Vial A) and SRM 968d L1 (Control), but exhibit a slight high bias for SRM 968f L2 (Vial B).

Six (6) labs reported results for both $25(\mathrm{OH}) \mathrm{D}_{2}$ and 3-epi-25(OH) $\mathrm{D}_{3}$ (labs 026, 056a, 060, 216, 241, and 272) and 6 additional labs (056b, 150, 214c, 228a, 249, and 255) reported results for one of the two metabolites in at least one of the study materials or the control (Table 3 and Table 4). Given the low concentrations of the $25(\mathrm{OH}) \mathrm{D}_{2}$ and the 3 -epi-25(OH) $\mathrm{D}_{3}$ metabolites in the study samples and the control, the variability of the results is much higher although the median values agree relatively well with the NIST values. 
Table 2. Summary of LC participant and NIST results for $25(\mathrm{OH}) \mathrm{D}_{3}(\mathrm{ng} / \mathrm{mL})$ in SRM $968 f \mathrm{~L} 1$ (Vial A), SRM 968f L2 (Vial B), and SRM 968d L1 (Control).

\begin{tabular}{|c|c|c|c|c|}
\hline & & SRM 968f L1 & SRM 968f L2 & SRM 968d L1 \\
\hline $\mathrm{Lab}$ & Method & Vial A & Vial B & Control \\
\hline 026 & LC-MS/MS & 13.7 & 15.7 & 12.6 \\
\hline 030b & LC-MS/MS & 21.0 & 21.8 & 12.5 \\
\hline 056a & LC-MS/MS & 12.0 & 16.6 & 11.4 \\
\hline 056b & LC-MS/MS & 12.9 & 16.8 & 12.9 \\
\hline 060 & LC-MS/MS & 12.9 & 18.3 & 12.6 \\
\hline 116 & LC-MS/MS & 14.8 & 17.6 & 13.9 \\
\hline 150 & LC-MS/MS & 13.0 & 17.0 & 13.0 \\
\hline $161 b$ & LC-MS/MS & 10.8 & 16.6 & 13.5 \\
\hline 194 & LC-MS/MS & 14.6 & 16.4 & 14.1 \\
\hline 197 & LC-MS/MS & 12.7 & 17.7 & 12.3 \\
\hline 199 & LC-MS/MS & 13.4 & 16.7 & 13.1 \\
\hline $204 b$ & LC-MS/MS & 12.6 & 16.2 & 12.4 \\
\hline 209 & LC-MS/MS & 14.6 & 20.1 & 11.8 \\
\hline 211 & LC-MS/MS & 13.0 & 19.0 & 13.1 \\
\hline $214 c$ & LC-MS/MS & 12.4 & 16.4 & 12.7 \\
\hline 215 & LC-MS/MS & 12.8 & 17.2 & 12.8 \\
\hline 216 & LC-MS/MS & 12.8 & 16.6 & 12.5 \\
\hline 217 & LC-MS/MS & 16.0 & 20.8 & 18.4 \\
\hline $221 b$ & LC-UV & 14.0 & 18.0 & 19.0 \\
\hline 225 & LC-MS/MS & 13.7 & 16.6 & 12.7 \\
\hline $228 a$ & LC-MS/MS & 13.2 & 15.8 & 12.4 \\
\hline 241 & LC-MS/MS & 12.5 & 17.4 & 12.9 \\
\hline 244 & LC-MS/MS & 12.3 & 15.6 & 12.7 \\
\hline 249 & LC-MS/MS & 12.7 & 18.0 & 13.3 \\
\hline 251 & LC-MS/MS & 16.0 & 20.0 & $\mathrm{n} / \mathrm{r}$ \\
\hline 255 & LC-MS/MS & 14.5 & 17.4 & 13.6 \\
\hline 259 & LC-MS/MS & 11.4 & 13.5 & 13.2 \\
\hline 271 & LC-MS/MS & 12.7 & 18.1 & 11.2 \\
\hline 272 & LC-MS/MS & 12.4 & 16.4 & 12.3 \\
\hline & $N$ & 29 & 29 & 28 \\
\hline 0 0 & Median & 12.9 & 17.0 & 12.8 \\
\hline בَ & MADe & 1.5 & 1.2 & 0.5 \\
\hline & CV\% & 11.5 & 7.0 & 4.1 \\
\hline & $N$ & 28 & 28 & 27 \\
\hline$\sum_{\Sigma}^{\infty}$ & Median & 12.9 & 16.9 & 12.7 \\
\hline ù & MADe & 1.3 & 1.0 & 0.4 \\
\hline בَ & CV\% & 10.4 & 6.1 & 3.5 \\
\hline & NIST Value & 12.3 & 15.6 & 12.4 \\
\hline & $U$ & 0.5 & 0.5 & 0.4 \\
\hline
\end{tabular}


Table 3. Summary of LC participant and NIST results for $25(\mathrm{OH}) \mathrm{D}_{2}(\mathrm{ng} / \mathrm{mL})$ in SRM $968 \mathrm{~L} 1$ (Vial A), SRM 968f L2 (Vial B), and SRM 968d L1 (Control).

\begin{tabular}{|c|c|c|c|c|}
\hline & & SRM 968f L1 & SRM 968f L2 & SRM 968d L1 \\
\hline Lab & Method & Vial A & Vial B & Control \\
\hline 026 & LC-MS/MS & 0.81 & 0.20 & 0.18 \\
\hline 056a & LC-MS/MS & 1.1 & 0.6 & 0.6 \\
\hline 056b & LC-MS/MS & 1.0 & $<0.6$ & $<0.6$ \\
\hline 060 & LC-MS/MS & 1.0 & 0.28 & 0.091 \\
\hline $214 c$ & LC-MS/MS & 0.9 & $<0.5$ & $<0.5$ \\
\hline 216 & LC-MS/MS & 0.90 & 0.23 & 0.18 \\
\hline 241 & LC-MS/MS & 1.5 & 0.0 & 0.06 \\
\hline 255 & LC-MS/MS & 0.8 & 0.0 & 0.0 \\
\hline 272 & LC-MS/MS & 1.2 & 0.41 & 0.24 \\
\hline & $N$ & 9 & 7 & 7 \\
\hline$\sum^{\infty}$ & Median & 1.0 & 0.23 & 0.18 \\
\hline ú & MADe & 0.15 & 0.27 & 0.13 \\
\hline 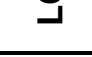 & CV\% & 15 & 116 & 73 \\
\hline & NIST Value & 0.85 & 0.17 & $0.1^{\star}$ \\
\hline & $U$ & 0.06 & 0.02 & -- \\
\hline
\end{tabular}

Table 4. Summary of LC participant and NIST results for 3-epi-25(OH)D $(\mathrm{ng} / \mathrm{mL})$ in SRM $968 f$ L1 (Vial A), SRM 968f L2 (Vial B), and SRM 968d L1 (Control).

\begin{tabular}{|c|c|c|c|c|}
\hline & & SRM $968 f$ L1 & SRM $968 f$ L2 & SRM 968d L1 \\
\hline $\mathrm{Lab}$ & Method & Vial A & Vial B & Control \\
\hline 026 & LC-MS/MS & 0.59 & 0.84 & 0.65 \\
\hline $056 a$ & LC-MS/MS & 0.76 & 0.46 & 0.46 \\
\hline 060 & LC-MS/MS & 0.57 & 0.88 & 0.54 \\
\hline 150 & LC-MS/MS & 1.0 & 1.0 & 1.0 \\
\hline 216 & LC-MS/MS & 0.58 & 0.50 & 0.67 \\
\hline $228 a$ & LC-MS/MS & 0.24 & 0.46 & 0.65 \\
\hline 241 & LC-MS/MS & 0.0 & 1.03 & 0.65 \\
\hline 249 & LC-MS/MS & 0.70 & 0.70 & 0.71 \\
\hline 272 & LC-MS/MS & 0.42 & 0.37 & 0.36 \\
\hline & $N$ & 9 & 9 & 9 \\
\hline$\sum_{\Sigma}^{M}$ & Median & 0.58 & 0.70 & 0.65 \\
\hline u & MADe & 0.24 & 0.35 & 0.09 \\
\hline 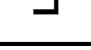 & $\mathrm{CV} \%$ & 42 & 50 & 14 \\
\hline & NIST Value & 0.72 & 1.1 & 0.65 \\
\hline & $U$ & 0.07 & 0.1 & 0.03 \\
\hline
\end{tabular}


Summer 2016 is the third comparability study in which a participant reported results for at least one of the dihydroxy metabolites, $24(\mathrm{R}), 25(\mathrm{OH})_{2} \mathrm{D}_{3}$, and the first study in which a participant reported results for vitamin $\mathrm{D}_{3}$ in each of the study materials. The results provided by participant 60 for these compounds are presented in Table 5.

Table 5. Lab 60's LC-MS/MS results for 24(R),25(OH $)_{2} \mathrm{D}_{3}$ and vitamin $\mathrm{D}_{3}(\mathrm{ng} / \mathrm{mL})$ in SRM $968 \mathrm{f}$ L1 (Vial A), SRM 968f L2 (Vial B), and SRM 968d L1 (Control).

\begin{tabular}{|l|c|c|}
\hline & $\begin{array}{c}\mathbf{2 4 ( R ) , 2 5 ( O H )} \mathbf{2}_{\mathbf{2}} \mathbf{D}_{\mathbf{3}} \\
(\mathbf{n g} / \mathbf{m L})\end{array}$ & $\begin{array}{c}\text { Vitamin } \mathbf{D}_{\mathbf{3}} \\
\text { (ng/mL) }\end{array}$ \\
\hline SRM 968f L1 (Vial A) & 0.668 & 1.21 \\
\hline SRM 968f L2 (Vial B) & 0.759 & 2.61 \\
\hline SRM 968d L1 (Control) & 0.505 & 0.831 \\
\hline
\end{tabular}

NIST has developed a candidate RMP for the determination of $24(\mathrm{R}), 25(\mathrm{OH})_{2} \mathrm{D}_{3}$ and has assigned reference values for this metabolite in SRM 972a Vitamin D Metabolites in Frozen Human Serum and SRM 2973 Vitamin D Metabolites in Frozen Human Serum (High Level). However, NIST is not providing values for $24(\mathrm{R}), 25(\mathrm{OH})_{2} \mathrm{D}_{3}$ for the VitDQAP study materials at this time. Furthermore, NIST does not currently have any clinical materials that have been assigned vitamin $\mathrm{D}_{3}$ values. 
Appendix A-1. Summary of immunoassay methods as reported by the study participants.

\begin{tabular}{|c|c|c|}
\hline $\begin{array}{c}\text { Laboratory } \\
\text { Number }\end{array}$ & IA Method & Vendor/kit* \\
\hline 127 & EIA & A \\
\hline 188 & CLIA & B \\
\hline 196 & CLIA & C \\
\hline $214 \mathrm{~b}$ & CLIA & D \\
\hline $218 a$ & CLIA & C \\
\hline 256 & CLIA & C \\
\hline 261 & CLIA & E \\
\hline 273 & EIA & $\mathrm{n} / \mathrm{r}$ \\
\hline
\end{tabular}

*NIST cannot endorse or recommend commercial products, therefore individual vendors/kits are indicated with a unique letter but not identified 
Appendix A-2. Summary of LC-MS ${ }^{\mathrm{n}}$ methods as reported by the study participants.

\begin{tabular}{|c|c|c|c|c|}
\hline $\begin{array}{l}\text { Laboratory } \\
\text { Number }\end{array}$ & $\begin{array}{c}\text { Internal } \\
\text { Standard (IS) }\end{array}$ & Sample Preparation & Chromatographic Conditions & Detection: MRM ions \\
\hline 26 & $\begin{array}{c}25(\mathrm{OH}) \mathrm{D}_{2}-d_{6} \text { and } \\
25(\mathrm{OH}) \mathrm{D}_{3}-d_{6}\end{array}$ & Liquid-liquid extraction method & $\begin{array}{l}\text { PFP column }(100 \mathrm{~mm} \times 3.2 \mathrm{~mm}) \\
\text { isocratic elution with } 82 \% \\
\text { methanol } / 18 \% \text { water; } \\
\text { flow } 0.4 \mathrm{~mL} / \mathrm{min}\end{array}$ & $\begin{array}{l}25(\mathrm{OH}) \mathrm{D}_{3} 401 / 365 \\
25(\mathrm{OH}) \mathrm{D}_{2} 413 / 355 \\
\text { 3-epi-25(OH) } \mathrm{D}_{3} 401 / 365\end{array}$ \\
\hline $30 \mathrm{~b}$ & $25(\mathrm{OH}) \mathrm{D}_{3}-d_{6}$ & $\begin{array}{l}\text { Samples were prepared with } \\
\text { disposable pipette extraction }\end{array}$ & $\begin{array}{l}\text { C18 column; isocratic elution with } \\
85 \% \text { acetonitrile } 15 \% \text { methanol; } \\
\text { flow } 0.5 \mathrm{~mL} / \mathrm{min}\end{array}$ & $25(\mathrm{OH}) \mathrm{D}_{3} 383 / 211$ \\
\hline $56 a$ & $\begin{array}{c}25(\mathrm{OH}) \mathrm{D}_{2}-d_{3} \\
25(\mathrm{OH}) \mathrm{D}_{3}-d_{6} \\
\text { 3-epi-25(OH) } \mathrm{D}_{3}-d_{3}\end{array}$ & $\begin{array}{l}\text { Samples were extracted with } \\
\text { hexane, evaporated, then } \\
\text { reconstituted with } 72 \% \\
\text { methanol } / 28 \% \text { water }\end{array}$ & $\begin{array}{l}\text { PFP column }(150 \mathrm{~mm} \times 2.1 \mathrm{~mm} \text {; } \\
2.7 \mu \mathrm{m}) \text {; isocratic elution with } \\
72 \% \text { methanol } / 28 \% \text { water; } \\
\text { flow } 0.35 \mathrm{~mL} / \mathrm{min}\end{array}$ & 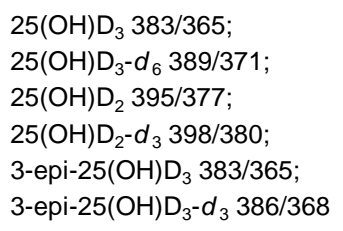 \\
\hline $56 b$ & $\mathrm{n} / \mathrm{r}$ & $\mathrm{n} / \mathrm{r}$ & $\mathrm{n} / \mathrm{r}$ & $\mathrm{n} / \mathrm{r}$ \\
\hline 60 & $\begin{array}{c}25(\mathrm{OH}) \mathrm{D}_{3}-d_{6} \\
25(\mathrm{OH}) \mathrm{D}_{3}-d_{3} \\
24,25(\mathrm{OH})_{2} \mathrm{D}_{3}-d_{6}\end{array}$ & $\begin{array}{l}\text { IS was added, and then samples } \\
\text { were extracted with acetonitrile, } \\
\text { evaporated, and reconstituted } \\
\text { with injection solvent }\end{array}$ & $\begin{array}{l}\text { PFP column }(100 \mathrm{~mm} \times 3.0 \mathrm{~mm} \text {; } \\
2.6 \mu \mathrm{m}) \text {; gradient with water, } \\
\text { methanol and acetonitrile }(0.05 \% \\
\text { formic acid) }\end{array}$ & $\begin{array}{l}25(\mathrm{OH}) \mathrm{D}_{3} 383 / 211 \\
25(\mathrm{OH}) \mathrm{D}_{3}-d_{6} 389 / 211 \\
25(\mathrm{OH}) \mathrm{D}_{2} 413 / 355 \\
3-\text {-epi-25(OH) } \\
\mathrm{D}_{3} 401 / 383\end{array}$ \\
\hline 116 & $25(\mathrm{OH}) \mathrm{D}_{3}-d_{6}$ & $\begin{array}{l}\text { Serum proteins were precipitated } \\
\text { with methanol }\end{array}$ & $\begin{array}{l}\text { Online SPE; reversed-phase } \\
\text { column; isocratic elution with } \\
95 \% \text { methanol } / 5 \% \text { water; } \\
\text { flow } 0.6 \mathrm{~mL} / \mathrm{min}\end{array}$ & $\begin{array}{l}25(\mathrm{OH}) \mathrm{D}_{3} 383 / 211 \\
25(\mathrm{OH}) \mathrm{D}_{3}-d_{6} 389 / 211 \\
25(\mathrm{OH}) \mathrm{D}_{2} 395 / 269\end{array}$ \\
\hline 150 & $\begin{array}{c}25(\mathrm{OH}) \mathrm{D}_{2}-d_{6} \text { and } \\
25(\mathrm{OH}) \mathrm{D}_{3}-d_{3}\end{array}$ & $\begin{array}{l}\text { Sample }(200 \mu \mathrm{L}) \text { was mixed with } \\
\text { IS solution, liquid-liquid extracted, } \\
\text { centrifuged, supernatant } \\
\text { evaporated, and reconstituted in } \\
\text { mobile phase }\end{array}$ & $\begin{array}{l}\text { PFP column }(100 \mathrm{~mm} \times 3.0 \mathrm{~mm} \text {; } \\
2.6 \mu \mathrm{m}) \text {; isocratic separation with } \\
74 \% \text { methanol } / 26 \% \text { water } \\
(2 \mathrm{mmol} / \mathrm{L} \text { ammonium acetate, } \\
0.1 \% \text { formic acid); } \\
\text { flow } 0.5 \mathrm{~mL} / \mathrm{min}\end{array}$ & $\begin{array}{l}25(\mathrm{OH}) \mathrm{D}_{3} 383 / 257,401 / 365 ; \\
25(\mathrm{OH}) \mathrm{D}_{2} 413 / 355,395 / 269\end{array}$ \\
\hline $161 b$ & $25(\mathrm{OH}) \mathrm{D}_{3}-d_{6}$ & Protein precipitation & $\begin{array}{l}\text { Reversed-phase column }(50 \mathrm{~mm} \times \\
2.1 \mathrm{~mm} ; 2.6 \mu \mathrm{m}) \text {; gradient with } \\
\text { methanol and water }(0.1 \% \text { formic } \\
\text { acid); flow } 0.5 \mathrm{~mL} / \mathrm{min}\end{array}$ & $\mathrm{APCl}$ \\
\hline 194 & $25(\mathrm{OH}) \mathrm{D}_{3}-d_{6}$ & $\begin{array}{l}\text { Protein crash followed by } \\
\text { evaporation and reconstitution }\end{array}$ & $\begin{array}{l}\text { Reversed-phase column }(50 \mathrm{~mm} \times \\
2.1 \mathrm{~mm})\end{array}$ & $\begin{array}{l}25(\mathrm{OH}) \mathrm{D}_{2} 395 / 119 \\
25(\mathrm{OH}) \mathrm{D}_{3} 383 / 211\end{array}$ \\
\hline 197 & $25(\mathrm{OH}) \mathrm{D}_{3}-d_{6}$ & $\begin{array}{l}\text { Precipitating agent added }(200 \mu \mathrm{L} \\
\text { with } 20 \mathrm{ng} \mathrm{IS}) \text { to each serum } \\
\text { sample }(200 \mu \mathrm{L}) \text {, calibrator and } \\
\text { control sample followed by mixing, } \\
\text { centrifugation, and analysis }\end{array}$ & $\begin{array}{l}\text { C18 column }(50 \mathrm{~mm} \times 4.6 \mathrm{~mm} \text {; } \\
5 \mu \mathrm{m}) \text {; column temp } 45^{\circ} \mathrm{C} \text {; gradient } \\
\text { with water and methanol }(0.1 \% \\
\text { formic acid); } \\
\text { flow } 1.0 \mathrm{~mL} / \mathrm{min}\end{array}$ & $\mathrm{n} / \mathrm{r}$ \\
\hline 199 & proprietary & proprietary & proprietary & proprietary \\
\hline $204 b$ & $\begin{array}{c}25(\mathrm{OH}) \mathrm{D}_{2}-d_{3} \\
25(\mathrm{OH}) \mathrm{D}_{3}-d_{6} \\
\text { 3-epi-25(OH) } \mathrm{D}_{3}-d_{3}\end{array}$ & $\begin{array}{l}\text { Protein crash with } 73 \% \text { methanol } \\
\text { followed by liquid-liquid extraction } \\
\text { with hexane, centrifugation, } \\
\text { evaporation, and reconstitution in } \\
\text { mobile phase }\end{array}$ & $\begin{array}{l}\text { PFP column }(100 \mathrm{~mm} \times 2.1 \mathrm{~mm} \text {; } \\
1.9 \mu \mathrm{m}) \text {; column temperature } 30{ }^{\circ} \mathrm{C} \text {; } \\
\text { isocratic elution with } 73 \% \\
\text { methanol } / 27 \% \text { water; } \\
\text { flow } 0.35 \mathrm{~mL} / \mathrm{min}\end{array}$ & 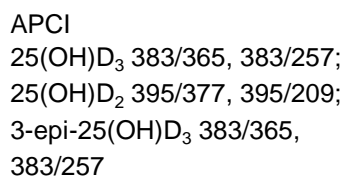 \\
\hline
\end{tabular}




\begin{tabular}{|c|c|c|c|c|}
\hline 209 & $25(\mathrm{OH}) \mathrm{D}_{3}-d_{6}$ & $\begin{array}{l}\text { Proteins were precipitated with } \\
5 \% \mathrm{ZnSO}_{4} \text { in } 95 \% \text { methanol }\end{array}$ & $\begin{array}{l}\text { C8 column }(50 \mathrm{~mm} \times 2 \mathrm{~mm} ; 5 \mu \mathrm{m}) \text {; } \\
\text { gradient with water/methanol; flow } \\
0.7 \mathrm{~mL} / \mathrm{min}\end{array}$ & $\begin{array}{l}\mathrm{APCl} \\
25(\mathrm{OH}) \mathrm{D}_{3} 383 / 229,383 / 211 ; \\
25(\mathrm{OH}) \mathrm{D}_{3}-d_{6} 389 / 211 ; \\
25(\mathrm{OH}) \mathrm{D}_{2} 395 / 269,395 / 119\end{array}$ \\
\hline 211 & $25(\mathrm{OH}) \mathrm{D}_{3}-d_{6}$ & $\begin{array}{l}\text { Proteins precipitated with } \\
\text { acetonitrile containing IS followed } \\
\text { by centrifugation }\end{array}$ & $\begin{array}{l}\text { Turbulent flow column }(32 \mathrm{~mm} x \\
4.6 \mathrm{~mm} ; 3 \mu \mathrm{m})\end{array}$ & $\begin{array}{l}25(\mathrm{OH}) \mathrm{D}_{3} 383 / 365 \text { (quant), } \\
383 / 257 \text { (qual); } 25(\mathrm{OH}) \mathrm{D}_{2} \\
395 / 209 \text { (quant), 395/377 } \\
\text { (qual) }\end{array}$ \\
\hline $214 c$ & $25(\mathrm{OH}) \mathrm{D}_{3}-d_{6}$ & $\begin{array}{l}\text { Samples were extracted with } \\
\text { hexane, centrifuged, evaporated, } \\
\text { and filtered }\end{array}$ & $\begin{array}{l}\text { Reversed-phase column }(50 \mathrm{~mm} \times \\
2.1 \mathrm{~mm}) \text {; isocratic elution with } 85 \% \\
\text { methanol/ } 15 \% \text { water } / 0.1 \% \text { formic } \\
\text { acid; } \\
\text { flow } 0.3 \mathrm{~mL} / \mathrm{min}\end{array}$ & $\begin{array}{l}25(\mathrm{OH}) \mathrm{D}_{3} 401 / 383 \\
25(\mathrm{OH}) \mathrm{D}_{3}-d_{6} 407 / 389 \\
25(\mathrm{OH}) \mathrm{D}_{2} 413 / 395\end{array}$ \\
\hline 215 & $25(\mathrm{OH}) \mathrm{D}_{3}-d_{6}$ & $\begin{array}{l}\text { Protein precipitation with } 80 \% \\
\text { methanol/ } 20 \% \text { isopropanol and } \\
\mathrm{ZnSO}_{4} ; \text { supernatant extracted } \\
\text { using SPE }\end{array}$ & $\begin{array}{l}\text { C18 column }(50 \mathrm{~mm} \times 2.1 \mathrm{~mm} \text {; } \\
2.6 \mu \mathrm{m}) \text { column; gradient with water } \\
(0.1 \% \text { formic acid, } 5 \mathrm{mmol} / \mathrm{L} \\
\text { ammonium formate) and methanol } \\
(0.05 \% \text { formic acid); flow } 0.2 \\
\mathrm{mL} / \mathrm{min} \text {. }\end{array}$ & $\begin{array}{l}\mathrm{ESI} \\
25(\mathrm{OH}) \mathrm{D}_{3} 401 / 383 \\
25(\mathrm{OH}) \mathrm{D}_{2} 413 / 395 \\
25(\mathrm{OH}) \mathrm{D}_{3}-d_{6} 407 / 389\end{array}$ \\
\hline 216 & $\begin{array}{l}\text { Derivatized } \\
\text { deuterated } \\
\text { standard }\end{array}$ & $\begin{array}{l}\text { Samples extracted using liquid- } \\
\text { liquid extraction then labeled with } \\
\text { a derivatization reagent }\end{array}$ & $\begin{array}{l}\text { Reversed-phase column ( } 150 \mathrm{~mm} \times \\
2.1 \mathrm{~mm}) \text {; gradient from } 25 \% \text { water } \\
(0.05 \% \text { formic acid) to } 50 \% \\
\text { acetonitrile }(0.05 \% \text { formic acid); } \\
\text { flow } 0.2 \mathrm{~mL} / \mathrm{min}\end{array}$ & $n / r$ \\
\hline 217 & $25(\mathrm{OH}) \mathrm{D}_{3}-d_{6}$ & $\begin{array}{l}\text { Protein precipitation with } \mathrm{ZnSO}_{4} \text { in } \\
\text { methanol followed by SPE }\end{array}$ & $\begin{array}{l}\text { C8 column }(50 \mathrm{~mm} \times 2.1 \mathrm{~mm} \text {; } \\
1.7 \mu \mathrm{m}) \text {; gradient of } 70 \% \text { to } 98 \% \\
\text { methanol (with } 0.1 \% \text { formic acid); } \\
\text { flow } 0.4 \mathrm{~mL} / \mathrm{min}\end{array}$ & $\begin{array}{l}25(\mathrm{OH}) \mathrm{D}_{3} 401 / 159 \text { (quant), } \\
401 / 383 \text { (qual); } 25(\mathrm{OH}) \mathrm{D}_{2} \\
413 / 83 \text { (quant), } 413 / 395 \\
\text { (qual) }\end{array}$ \\
\hline 225 & $25(\mathrm{OH}) \mathrm{D}_{3}-d_{6}$ & $\begin{array}{l}\text { Liquid-liquid extraction with } \\
\text { hexanes }\end{array}$ & $\begin{array}{l}\text { PFP column }(100 \mathrm{~mm} \times 2.1 \mathrm{~mm} \text {; } \\
1.7 \mu \mathrm{m}) \text {; gradient with } \\
\text { methanol/water }\end{array}$ & $\begin{array}{l}25(\mathrm{OH}) \mathrm{D}_{3} 401 / 107 \\
25(\mathrm{OH}) \mathrm{D}_{2} 413 / 83\end{array}$ \\
\hline $228 a$ & $n / r$ & $n / r$ & $n / r$ & $n / r$ \\
\hline 241 & $25(\mathrm{OH}) \mathrm{D}_{3}-d_{6}$ & $\begin{array}{l}\text { Acetonitrile containing the IS } \\
(100 \mu \mathrm{L}) \text { added to sample ( } 200 \\
\mu \mathrm{L}) \text { to precipate proteins, followed } \\
\text { by extraction with hexane, } \\
\text { centrifugation, removal of } \\
\text { supernatant, evaporation, and } \\
\text { reconstitution in methanol solution }\end{array}$ & $\begin{array}{l}\text { PFP column }(100 \mathrm{~mm} \times 2.1 \mathrm{~mm} \text {; } \\
2.6 \mu \mathrm{m}) ; \text { gradient starting with } 50 \% \\
\text { methanol }(0.1 \% \text { formic acid }), 50 \% \\
\text { water }(0.1 \% \text { formic acid })\end{array}$ & $\begin{array}{l}\mathrm{APCl} \\
25(\mathrm{OH}) \mathrm{D}_{3} 383 / 211 \text { (quant), } \\
383 / 229 \text { (qual); } 25(\mathrm{OH}) \mathrm{D}_{2} \\
395 / 119 \text { (quant), } 395 / 211 \\
\text { (qual); } 25(\mathrm{OH}) \mathrm{D}_{3}-d_{6} 389 / 211\end{array}$ \\
\hline 244 & $25(\mathrm{OH}) \mathrm{D}_{3}-d_{6}$ & $\begin{array}{l}\text { Protein precipitation followed by } \\
\text { filtration }\end{array}$ & $\begin{array}{l}\mathrm{CN} \text { column; mobile phase } \\
\text { consisting of distilled water (formic } \\
\text { acid) and methanol }\end{array}$ & $\begin{array}{l}25(\mathrm{OH}) \mathrm{D}_{3} 383 / 211 \\
25(\mathrm{OH}) \mathrm{D}_{3}-d_{6} 389 / 211 \\
25(\mathrm{OH}) \mathrm{D}_{2} 395 / 269\end{array}$ \\
\hline 249 & $\left|\begin{array}{c}25(\mathrm{OH}) \mathrm{D}_{2}-d_{3} \\
25(\mathrm{OH}) \mathrm{D}_{3}-d_{6} \\
\text { 3-epi-25(OH) } \mathrm{D}_{3}-d_{3}\end{array}\right|$ & $\begin{array}{l}\text { Serum was deproteinated with } \\
\mathrm{NaOH} \text { and } 90 \% \text { acetonitrile/ } 10 \% \\
\text { methanol followed by SPE }\end{array}$ & $\begin{array}{l}\text { PFP column (100 } \mathrm{mm} \times 2.1 \mathrm{~mm} \text {; } \\
1.8 \mu \mathrm{m}) ; \text { gradient separation with } \\
\text { water }(2 \mathrm{mmol} / \mathrm{L} \text { ammonium } \\
\text { acetate }) \text { and methanol; } \\
\text { flow } 0.35 \mathrm{~mL} / \mathrm{min}\end{array}$ & $\begin{array}{l}25(\mathrm{OH}) \mathrm{D}_{3} 401 / 159 \\
25(\mathrm{OH}) \mathrm{D}_{2} 413 / 159\end{array}$ \\
\hline 251 & $\begin{array}{c}25(\mathrm{OH}) \mathrm{D}_{2}-d_{3} \text { and } \\
25(\mathrm{OH}) \mathrm{D}_{3}-d_{3}\end{array}$ & $\begin{array}{l}\text { Protein precipitation followed by } \\
\text { SPE }\end{array}$ & $\begin{array}{l}\text { Phenyl column }(50 \mathrm{~mm} \times 2.1 \mathrm{~mm} \text {; } \\
1.7 \mu \mathrm{m}) \text {; gradient with water and } \\
\text { methanol ( } 0.1 \% \text { formic acid, } \\
2 \mathrm{mmol} / \mathrm{L} \text { ammonium acetate); flow } \\
0.45 \mathrm{~mL} / \mathrm{min}\end{array}$ & $\begin{array}{l}25(\mathrm{OH}) \mathrm{D}_{3} 401 / 159 \text { (quant), } \\
401 / 365 \text { (qual); } 25(\mathrm{OH}) \mathrm{D}_{2} \\
413 / 83 \text { (quant), 413/355 } \\
\text { (qual); } 25(\mathrm{OH}) \mathrm{D}_{3}-d_{3} 404 / 162 ; \\
25(\mathrm{OH}) \mathrm{D}_{2}-d_{3} 416 / 358\end{array}$ \\
\hline 255 & $\begin{array}{c}\text { deuterium labeled } \\
\text { compound }\end{array}$ & $\begin{array}{l}\text { Samples were extracted and } \\
\text { derivatized with 4-phenyl-1,2,4- } \\
\text { triazoline-3,5-dione }\end{array}$ & $\begin{array}{l}\text { Reversed-phase column }(50 \mathrm{~mm} \times \\
2.1 \mathrm{~mm}) ; \text { gradient with methanol; } \\
\text { flow } 0.5 \mathrm{~mL} / \mathrm{min}\end{array}$ & $\begin{array}{l}25(\mathrm{OH}) \mathrm{D}_{3} 607 / 298 \\
25(\mathrm{OH}) \mathrm{D}_{2} 619 / 298\end{array}$ \\
\hline
\end{tabular}




\begin{tabular}{|c|c|c|c|c|}
\hline 259 & $25(\mathrm{OH}) \mathrm{D}_{3}-d_{6}$ & $\begin{array}{l}\text { Liquid-liquid extraction using } \\
\text { hexane }\end{array}$ & $\begin{array}{l}\text { C8 column; gradient with } \\
\text { methanol } / \text { water } / 0.1 \% \text { formic acid; } \\
\text { column temperature } 40^{\circ} \mathrm{C} \text {; flow } \\
\text { from } 0.6 \mathrm{~mL} / \mathrm{min} \text { to } 0.9 \mathrm{~mL} / \mathrm{min}\end{array}$ & $\begin{array}{l}25(\mathrm{OH}) \mathrm{D}_{3} 401 / 365 \\
25(\mathrm{OH}) \mathrm{D}_{2} 413 / 355 \\
25(\mathrm{OH}) \mathrm{D}_{3}-d_{6} 407 / 371 \\
\end{array}$ \\
\hline 271 & $25(\mathrm{OH}) \mathrm{D}_{3}-d_{6}$ & Protein precipitation & $\begin{array}{l}\text { C8 column }(3 \mu \mathrm{m}) \text {; gradient with } \\
\text { water/acetonitrile/0.1 \% formic acid; } \\
\text { flow } 0.7 \mathrm{~mL} / \mathrm{min}\end{array}$ & $\begin{array}{l}25(\mathrm{OH}) \mathrm{D}_{3} 383 / 229 \\
25(\mathrm{OH}) \mathrm{D}_{2} 395 / 119\end{array}$ \\
\hline 272 & $\begin{array}{l}\text { Isotopically labeled } \\
\text { internal standards }\end{array}$ & $\begin{array}{l}\text { Samples were precipitated and } \\
\text { centrifuged before injection }\end{array}$ & $\begin{array}{l}\text { Analytical column and trap column } \\
\text { from a kit; separation using a binary } \\
\text { gradient system and an additional } \\
\text { isocratic pump }\end{array}$ & $\begin{array}{l}25(\mathrm{OH}) \mathrm{D}_{3} 383 / 257,383 / 299 ; \\
\text { IS (1): 386/257, 386/232; } \\
\text { 25(OH)D } 395 / 269,395 / 251 ; \\
\text { 3-epi-25(OH)D } \mathrm{D}_{3} 383 / 257 \\
\text { 383/299; } \\
\text { 3-epi-25(OH)D } \mathrm{D}_{2} 395 / 269 \\
\text { 395/251; } \\
\text { IS (2): 386/257, 386/232 }\end{array}$ \\
\hline
\end{tabular}

C18 = octadecyl; C8 = octyl; PFP = pentafluorophenyl; SPE = solid phase extraction; CN = cyano;

$\mathrm{MRM}$ = multiple reaction monitoring; quant/qual = quantitative/qualitative ions; $\mathrm{n} / \mathrm{r}=$ not reported;

$\mathrm{APCl}=$ atmospheric pressure chemical ionization; $\mathrm{ESI}=$ electrospray ionization

Appendix A-3. Summary of LC-UV methods as reported by the study participants.

\begin{tabular}{|c|c|l|l|l|}
\hline $\begin{array}{c}\text { Laboratory } \\
\text { Number }\end{array}$ & $\begin{array}{c}\text { Internal } \\
\text { Standard (IS) }\end{array}$ & \multicolumn{1}{|c|}{ Sample Preparation } & Chromatographic Conditions & Wavelength \\
\hline \multirow{3}{*}{110} & $\mathrm{n} / \mathrm{a}$ & $\begin{array}{l}\text { Samples }(500 \mu \mathrm{L}) \text { were mixed with } \\
\text { ethanol }(500 \mu \mathrm{L}) \text {, extracted twice } \\
\text { with hexane/methylene chloride } \\
(5: 1), \text { evaporated, and } \\
\text { reconstituted }\end{array}$ & $\begin{array}{l}\text { C18 column }(2.1 \mathrm{~mm} \times 100 \mathrm{~mm} ; \\
\text { acetonitrile/ } 15 \% \text { methanol and } \\
\text { isopropanol }(100 \%)\end{array}$ & $267 \mathrm{~nm}$ \\
\hline $221 \mathrm{~b}$ & laurophenone & $\begin{array}{l}\text { Protein crash with acetonitrile } \\
\text { solution containing IS, followed by } \\
\text { SPE with C18, elution with } \\
\text { methanol/acetonitrile solution, } \\
\text { evaporation, and reconstitution } \\
\text { with acetonitrile }\end{array}$ & $\begin{array}{l}\text { CN column }(150 \mathrm{~mm} \times 5 \mathrm{~mm} ; \\
\text { methanol } / \text { water/formic acid; column } \\
\text { temperature } 47^{\circ} \mathrm{C}\end{array}$ & $275 \mathrm{~nm}$ \\
\hline
\end{tabular}

C18 = octadecyl; SPE = solid phase extraction; CN = cyano; n/a = not applicable 
Appendix B. Raw participant data and NIST results for 25(OH)D 2 , 25(OH) $\mathrm{D}_{3}$, 3-epi-25(OH) $\mathrm{D}_{3}$, and 25(OH)D $\mathrm{D}_{\text {Total }}$ in SRM $968 f \mathrm{~L} 1$ (Vial A), SRM 968f L2 (Vial B), and SRM 968d L1 (Control).

\begin{tabular}{|c|c|c|c|c|c|c|c|c|c|c|}
\hline & & \multicolumn{3}{|c|}{$25(\mathrm{OH}) \mathrm{D}_{2}(\mathrm{ng} / \mathrm{mL})$} & \multicolumn{3}{|c|}{$25(\mathrm{OH}) \mathrm{D}_{3}(\mathrm{ng} / \mathrm{mL})$} & \multicolumn{3}{|c|}{$25(\mathrm{OH}) \mathrm{D}_{\text {Total }}(\mathrm{ng} / \mathrm{mL})$} \\
\hline & & VitDQAP-I & VitDQAP-II & SRM 968d L1 & VitDQAP-I & VitDQAP-II & SRM 968d L1 & VitDQAP-I & VitDQAP-II & SRM 968d L1 \\
\hline $\mathrm{Lab}$ & Method & Vial A & Vial B & Control & Vial A & Vial B & Control & Vial A & Vial B & Control \\
\hline 026 & LC-MS/MS & 0.8 & 0.2 & 0.2 & 13.7 & 15.7 & 12.6 & 14.5 & 15.9 & 12.8 \\
\hline $030 \mathrm{~b}$ & LC-MS/MS & 0 & 0 & 0 & 21.0 & 21.8 & 12.5 & 21.0 & 21.8 & 12.5 \\
\hline $056 a$ & LC-MS/MS & 1.1 & 0.6 & 0.6 & 12.0 & 16.6 & 11.4 & 13.1 & 17.2 & 12.0 \\
\hline 056b & LC-MS/MS & 1.0 & $<0.6$ & $<0.6$ & 12.9 & 16.8 & 12.9 & 13.9 & 16.8 & 12.9 \\
\hline 060 & LC-MS/MS & 1.0 & 0.3 & 0.1 & 12.9 & 18.3 & 12.6 & 13.9 & 18.6 & 12.7 \\
\hline 110 & LC-UV & $n / r$ & $n / r$ & $n / r$ & $\mathrm{n} / \mathrm{r}$ & $n / r$ & $n / r$ & 13.0 & 18.4 & 12.5 \\
\hline 116 & LC-MS/MS & $<3.3$ & $<3.3$ & $<3.3$ & 14.8 & 17.6 & 13.9 & 14.8 & 17.6 & 13.9 \\
\hline 127 & EIA & $n / a$ & $n / a$ & $n / a$ & $\mathrm{n} / \mathrm{a}$ & $\mathrm{n} / \mathrm{a}$ & $\mathrm{n} / \mathrm{a}$ & 21.8 & 21.0 & 18.6 \\
\hline 150 & LC-MS/MS & $<5$ & $<5$ & $<5$ & 13.0 & 17.0 & 13.0 & 13.0 & 17.0 & 13.0 \\
\hline $161 \mathrm{~b}$ & LC-MS/MS & $<4$ & $<4$ & $<4$ & 10.8 & 16.6 & 13.5 & 10.8 & 16.6 & 13.5 \\
\hline 188 & CLIA & $n / a$ & $n / a$ & $n / a$ & $\mathrm{n} / \mathrm{a}$ & $\mathrm{n} / \mathrm{a}$ & $\mathrm{n} / \mathrm{a}$ & 17.5 & 14.5 & 12.5 \\
\hline 194 & LC-MS/MS & $<7$ & $<7$ & $<7$ & 14.6 & 16.4 & 14.1 & 14.6 & 16.4 & 14.1 \\
\hline 196 & CLIA & n/a & $n / a$ & $n / a$ & $\mathrm{n} / \mathrm{a}$ & $\mathrm{n} / \mathrm{a}$ & $\mathrm{n} / \mathrm{a}$ & 18.8 & 16.9 & 14.6 \\
\hline 197 & LC-MS/MS & $<5$ & $<5$ & 0 & 12.7 & 17.7 & 12.3 & 12.7 & 17.7 & 12.3 \\
\hline 199 & LC-MS/MS & $<2.0$ & $<2.0$ & $<2.0$ & 13.4 & 16.7 & 13.1 & 13.4 & 16.7 & 13.1 \\
\hline $204 \mathrm{~b}$ & LC-MS/MS & $n / r$ & $\mathrm{n} / \mathrm{r}$ & $\mathrm{n} / \mathrm{r}$ & 12.6 & 16.2 & 12.4 & 12.6 & 16.2 & 12.4 \\
\hline 209 & LC-MS/MS & $<1.0$ & $<1.0$ & $<1.0$ & 14.6 & 20.1 & 11.8 & 14.6 & 20.1 & 11.8 \\
\hline 211 & LC-MS/MS & 0 & 0 & 0 & 13.0 & 19.0 & 13.1 & 13.0 & 19.0 & 13.1 \\
\hline $214 \mathrm{~b}$ & CLIA & $n / a$ & $n / a$ & $n / a$ & $\mathrm{n} / \mathrm{a}$ & $\mathrm{n} / \mathrm{a}$ & $\mathrm{n} / \mathrm{a}$ & 18.5 & 15.0 & 17.2 \\
\hline $214 c$ & LC-MS/MS & 0.9 & $<0.5$ & $<0.5$ & 12.4 & 16.4 & 12.7 & 13.3 & 16.4 & 12.7 \\
\hline 215 & LC-MS/MS & $<2$ & $<2$ & $<2$ & 12.8 & 17.2 & 12.8 & 12.8 & 17.2 & 12.8 \\
\hline 216 & LC-MS/MS & 0.9 & 0.2 & 0.2 & 12.8 & 16.6 & 12.5 & 13.7 & 16.8 & 12.7 \\
\hline 217 & LC-MS/MS & 0 & 0 & 0 & 16.0 & 20.8 & 18.4 & 16.0 & 20.8 & 18.4 \\
\hline $218 a$ & CLIA & n/a & $\mathrm{n} / \mathrm{a}$ & $\mathrm{n} / \mathrm{a}$ & $n / a$ & $\mathrm{n} / \mathrm{a}$ & $\mathrm{n} / \mathrm{a}$ & 12.4 & 14.2 & 16.5 \\
\hline $221 b$ & LC-UV & 0 & 0 & 0 & 14.0 & 18.0 & 19.0 & 14.0 & 18.0 & 19.0 \\
\hline 225 & LC-MS/MS & $<5$ & $<5$ & $<5$ & 13.7 & 16.6 & 12.7 & 13.7 & 16.6 & 12.7 \\
\hline $228 a$ & LC-MS/MS & $n / r$ & $n / r$ & $\mathrm{n} / \mathrm{r}$ & 13.2 & 15.8 & 12.4 & 13.2 & 15.8 & 12.4 \\
\hline 241 & LC-MS/MS & 1.5 & 0.0 & 0.1 & 12.5 & 17.4 & 12.9 & 14.0 & 17.4 & 13.0 \\
\hline 244 & LC-MS/MS & $<5$ & $<5$ & $<5$ & 12.3 & 15.6 & 12.7 & 12.3 & 15.6 & 12.7 \\
\hline 249 & LC-MS/MS & $<0.8$ & $<0.8$ & $<0.8$ & 12.7 & 18.0 & 13.3 & 12.7 & 18.0 & 13.3 \\
\hline 251 & LC-MS/MS & $<4$ & $<4$ & $n / r$ & 16.0 & 20.0 & $n / r$ & 16.0 & 20.0 & $\mathrm{n} / \mathrm{r}$ \\
\hline 255 & LC-MS/MS & 0.8 & 0.0 & 0.0 & 14.5 & 17.4 & 13.6 & 15.3 & 17.4 & 13.6 \\
\hline 256 & CLIA & $n / a$ & $n / a$ & $\mathrm{n} / \mathrm{a}$ & $\mathrm{n} / \mathrm{a}$ & $\mathrm{n} / \mathrm{a}$ & $\mathrm{n} / \mathrm{a}$ & 19.3 & 15.2 & 12.4 \\
\hline 259 & LC-MS/MS & $n / d$ & $n / d$ & $n / d$ & 11.4 & 13.5 & 13.2 & 11.4 & 13.5 & 13.2 \\
\hline 261 & CLIA & $n / a$ & $n / a$ & $\mathrm{n} / \mathrm{a}$ & $\mathrm{n} / \mathrm{a}$ & $\mathrm{n} / \mathrm{a}$ & $\mathrm{n} / \mathrm{a}$ & 19.2 & 35.9 & 13.5 \\
\hline 271 & LC-MS/MS & $<4.0$ & $<4.0$ & $<4.0$ & 12.7 & 18.1 & 11.2 & 16.7 & 22.1 & 15.2 \\
\hline 272 & LC-MS/MS & 1.2 & 0.4 & 0.2 & 12.4 & 16.4 & 12.3 & 13.6 & 16.8 & 12.6 \\
\hline 273 & EIA & $n / a$ & $n / a$ & $n / a$ & $\mathrm{n} / \mathrm{a}$ & $\mathrm{n} / \mathrm{a}$ & $\mathrm{n} / \mathrm{a}$ & 18.6 & 18.1 & 15.1 \\
\hline
\end{tabular}

\begin{tabular}{|c|c|c|}
\hline \multicolumn{3}{|c|}{ 3-epi-25(OH)D ${ }_{3}(\mathrm{ng} / \mathrm{mL})$} \\
\hline VitDQAP-I & VitDQAP-II & SRM 968d L1 \\
\hline Vial A & Vial B & Control \\
\hline 0.6 & 0.8 & 0.7 \\
\hline$n / r$ & $\mathrm{n} / \mathrm{r}$ & $\mathrm{n} / \mathrm{r}$ \\
\hline 0.8 & 0.5 & 0.5 \\
\hline$n / r$ & $n / r$ & $n / r$ \\
\hline 0.6 & 0.9 & 0.5 \\
\hline$n / r$ & $n / r$ & $\mathrm{n} / \mathrm{r}$ \\
\hline$<4$ & $<4$ & $<4$ \\
\hline$n / a$ & $\mathrm{n} / \mathrm{a}$ & $\mathrm{n} / \mathrm{a}$ \\
\hline 1.0 & 1.0 & 1.0 \\
\hline$n / r$ & $n / r$ & $n / r$ \\
\hline$n / a$ & $n / a$ & $n / a$ \\
\hline$n / r$ & $\mathrm{n} / \mathrm{r}$ & $n / r$ \\
\hline$n / a$ & $n / a$ & $n / a$ \\
\hline$n / r$ & $\mathrm{n} / \mathrm{r}$ & $n / r$ \\
\hline$n / r$ & $\mathrm{n} / \mathrm{r}$ & $n / r$ \\
\hline $\mathrm{n} / \mathrm{r}$ & $n / r$ & $n / r$ \\
\hline $\mathrm{n} / \mathrm{r}$ & $n / r$ & $n / r$ \\
\hline 0 & 0 & 0 \\
\hline $\mathrm{n} / \mathrm{a}$ & $n / a$ & $\mathrm{n} / \mathrm{a}$ \\
\hline $\mathrm{n} / \mathrm{r}$ & $\mathrm{n} / \mathrm{r}$ & $\mathrm{n} / \mathrm{r}$ \\
\hline$n / r$ & $n / r$ & $\mathrm{n} / \mathrm{r}$ \\
\hline 0.6 & 0.5 & 0.7 \\
\hline$n / r$ & $n / r$ & $n / r$ \\
\hline$n / a$ & $n / a$ & $\mathrm{n} / \mathrm{a}$ \\
\hline$n / r$ & $n / r$ & $n / r$ \\
\hline$n / r$ & $n / r$ & $\mathrm{n} / \mathrm{r}$ \\
\hline 0.2 & 0.5 & 0.7 \\
\hline 0.0 & 1.0 & 0.6 \\
\hline$n / r$ & $\mathrm{n} / \mathrm{r}$ & $\mathrm{n} / \mathrm{r}$ \\
\hline 0.7 & 0.7 & 0.7 \\
\hline$n / r$ & $n / r$ & $n / r$ \\
\hline$n / r$ & $n / r$ & $n / r$ \\
\hline$n / a$ & $\mathrm{n} / \mathrm{a}$ & $\mathrm{n} / \mathrm{a}$ \\
\hline $\mathrm{n} / \mathrm{r}$ & $n / r$ & $\mathrm{n} / \mathrm{r}$ \\
\hline$n / a$ & $n / a$ & $n / a$ \\
\hline$n / r$ & $\mathrm{n} / \mathrm{r}$ & $\mathrm{n} / \mathrm{r}$ \\
\hline 0.4 & 0.4 & 0.4 \\
\hline $\mathrm{n} / \mathrm{a}$ & $\mathrm{n} / \mathrm{a}$ & $\mathrm{n} / \mathrm{a}$ \\
\hline
\end{tabular}

$\mathrm{n} / \mathrm{a}=$ not applicable (for immunoassay methods); $\mathrm{n} / \mathrm{r}=$ not reported or not determined; $\mathrm{n} / \mathrm{d}=$ not detected; $<\mathrm{X}=$ less than a reported quantitation limit of $\mathrm{X}$

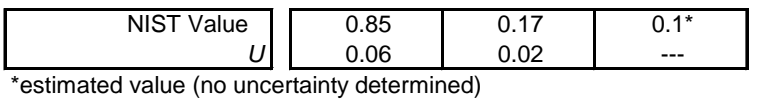

\begin{tabular}{|c|c|c|}
\hline 12.3 & 15.6 & 12.4 \\
0.5 & 0.5 & 0.4 \\
\hline
\end{tabular}

\begin{tabular}{|c|c|c|}
\hline 13.2 & 15.8 & 12.5 \\
0.5 & 0.5 & 0.4 \\
\hline
\end{tabular}

\begin{tabular}{|l|l|l|}
\hline 0.72 & 1.1 & 0.65 \\
0.07 & 0.2 & 0.03 \\
\hline
\end{tabular}

